\title{
Study on Bending Strength of Web-Bolted Moment Joints of Aluminum Alloy Beam Exposed to Fire
}

\author{
HISASHI ISHII ${ }^{1}$, TAKEO HIRASHIMA ${ }^{2}$, and HIDEKI UESUGI ${ }^{3}$ \\ ${ }^{1}$ Global Business Department \\ JS Group Corporation \\ 3-3-2, Nihombashihamacho, Chuo-ku, Tokyo, 103-0007, Japan \\ ${ }^{2}$ Department of Architecture \\ Graduate School of Engineering, Chiba University \\ 1-33, Yayoi-cho, Inage-ku, Chiba-city 263-8522, Japan \\ ${ }^{3}$ Chiba University \\ 1-33, Yayoi-cho, Inage-ku, Chiba-city 263-8522, Japan
}

\begin{abstract}
This study narrows the application temperature field of aluminum alloy to $350{ }^{\circ} \mathrm{C}$ or less, and examines the strength of web-bolted moment joints within that temperature range. Bending strength of web-bolted moment joints of aluminum alloy exposed to fire is investigated experimentally and analytically. It is observed that if splice plate length and the beam section are designed appropriately, it is possible that maximum bending strength is fully realized with the web-bolted moment joints. The transmission mechanism of the bending moments is thought to be based on prying action between the flanges and splice plate side edge. The effect of prying action contributes to the maximum bending strength. Maximum bending strength ratio is $90-60 \%$.
\end{abstract}

KEYWORDS: aluminum alloy beam, web-bolted joint, prying action, structural design, bending strength, FEM.

\section{NOMENCLATURE LISTING}

\begin{tabular}{|c|c|c|c|}
\hline$B$ & width of $\mathrm{H}$ and $\mathrm{DW}$ beam $(\mathrm{mm})$ & ${ }_{i} q_{x}$ & $\begin{array}{l}\text { prying force of prying element on splice } \\
\text { plate portion in } \mathrm{x} \text { direction }(\mathrm{kN})\end{array}$ \\
\hline$d$ & prying element length (mm) & $j q_{x}$ & $\begin{array}{l}\text { prying force of prying element on web } \\
\text { portion in } \mathrm{x} \text { direction }(\mathrm{kN})\end{array}$ \\
\hline$H$ & height of $\mathrm{H}$ and $\mathrm{DW}$ beam (mm) & $i q y$ & $\begin{array}{l}\text { prying force of prying element on splice } \\
\text { plate portion in y direction }(\mathrm{kN})\end{array}$ \\
\hline$h_{1}$ & $\begin{array}{l}\text { distance from upper flange face to center } \\
\text { of upper bolt hole }(\mathrm{mm})\end{array}$ & ${ }_{j} q_{y}$ & $\begin{array}{l}\text { prying force of prying element on web } \\
\text { portion in y direction }(\mathrm{kN})\end{array}$ \\
\hline$h_{2}$ & $\begin{array}{l}\text { distance from upper flange face to center } \\
\text { of lower bolt hole ( } \mathrm{mm})\end{array}$ & $t_{w}$ & web thickness (mm) \\
\hline$M$ & bending moment $(\mathrm{kN} \cdot \mathrm{m})$ & $t_{f}$ & flange thickness (mm) \\
\hline$M_{P}$ & peak bending moment $(\mathrm{kN} \cdot \mathrm{m})$ & Greek & \\
\hline$P_{B U}$ & $\begin{array}{l}\text { bearing force of upper bolt on web } \\
\text { portion }(\mathrm{kN})\end{array}$ & $\delta$ & displacement $(\mathrm{mm})$ \\
\hline$P_{B L}$ & $\begin{array}{l}\text { bearing force of lower bolt on web } \\
\text { portion }(\mathrm{kN})\end{array}$ & $\theta$ & deflection slope angle \\
\hline$P_{C}$ & compression force of flange contact $(\mathrm{kN})$ & \multicolumn{2}{|c|}{ subscripts } \\
\hline$P_{L C}$ & $\begin{array}{l}\text { prying force between upper flange and } \\
\text { splice plate on center side }(\mathrm{kN})\end{array}$ & C & compression \\
\hline$P_{L E}$ & $\begin{array}{l}\text { prying force between upper flange and } \\
\text { splice plate on edge side }(\mathrm{kN})\end{array}$ & $L$ & prying \\
\hline & & $P$ & in \\
\hline
\end{tabular}




\section{INTRODUCTION}

This study investigates the use of beams in atriums and pool roofs as architectural structures which employ aluminum alloys, and especially consider the transfer of the bending moments of beam joints exposed to fire. A temperature range of $20{ }^{\circ} \mathrm{C}$ to $350{ }^{\circ} \mathrm{C}$ is investigated; heating of specimens is by the use of an electric furnace.

Traditionally, the purpose of friction joints of beams has been to provide rigidity. These joints have a highstrength bolt going through splice plates, flanges and webs of H-beam steel beam sections (see Fig. 1a and Fig. 2). However, this type of joint is difficult to design and construct, because it is affected by bending moments (see Fig. 1b). It is possible to control the bending moment by using the web-bolted moment joint shown in Fig. 3. This type of joint has already been proposed [1]. In Fig. 3, the web-bolted moment joint connects only the web sections with high-strength bolts through the splice plates; the flange is not connected.

In an experiment of a steel H-beam [1], this connection was shown to adequately transmit bending moments. However, the direction of the bolt shearing force is different from that of a conventional bolt joint connection [2], which is the vertical direction. Consequently, in the web-bolted joint, the shearing force acts parallel to the axis of the member, and the splice plates are therefore bent as a result [3].

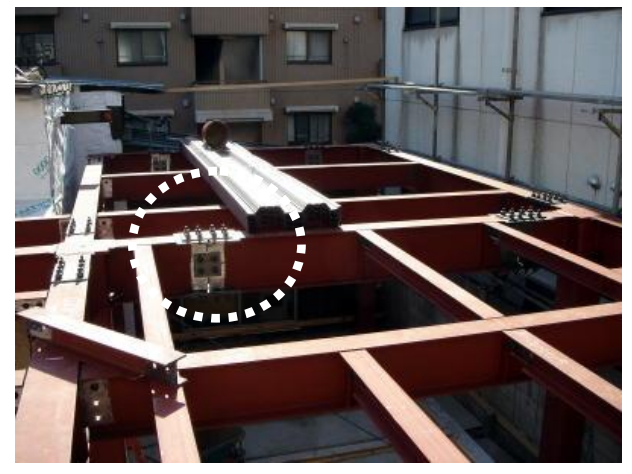

(a)

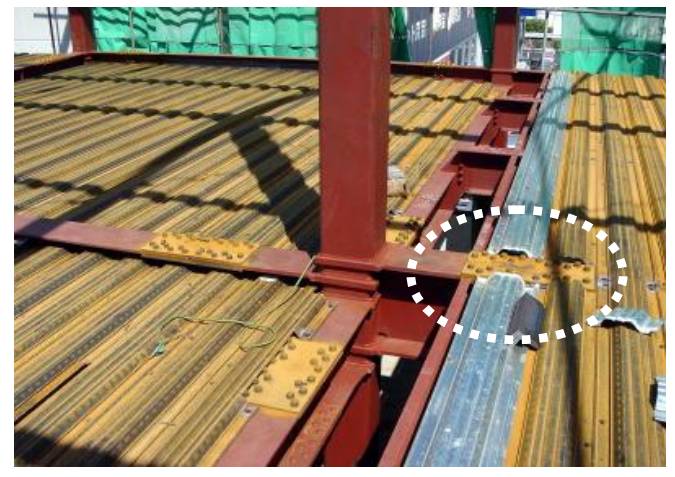

(b)

Fig. 1. Photographs of: (a) traditional friction joint of a beam; (b) details on flange side of bolt and deck plate.

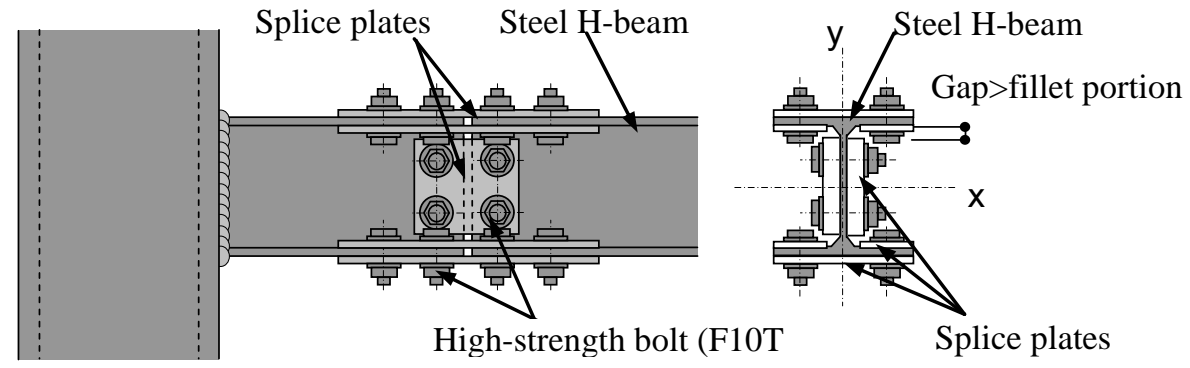

Fig. 2. Traditional friction joint of a beam.
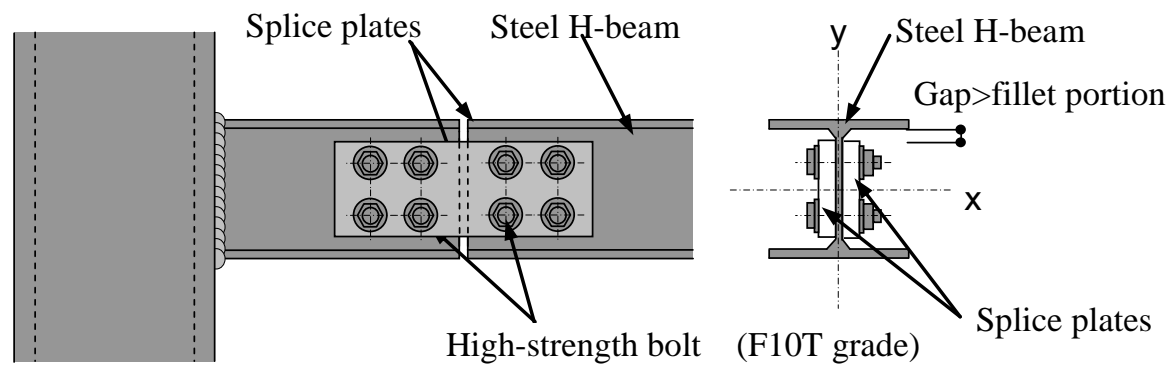

Fig. 3. Web-bolted moment joint in $\mathrm{H}$-shape steel beam. 


\section{PURPOSE OF THIS STUDY}

This study examines web-bolted moment joints made from aluminum alloy members. Examples are shown in Fig. 4 [4] and Fig. 5. In the web-bolted moment joints, the heights of the splice plates can be varied to depths that are within $1 \mathrm{~mm}$ between the beam flanges and the edges of the splices. This lower gap limit allows considerable enhancement of the joint by increasing the height of the plate, unlike steel members. Therefore, the web-bolted moment joint is a method for beams extruded with high accuracy, such as with aluminum alloy beams. To use these connections in hollow beam sections, the splice plates are inserted without gaps, as shown in Fig. 5.

It is also easy to form the hollow section in aluminum alloy members instead of the $\mathrm{H}$-steel beam that is commonly used. This joint method is referred to as a web-bolted moment joint of a double web-beam of aluminum alloy.

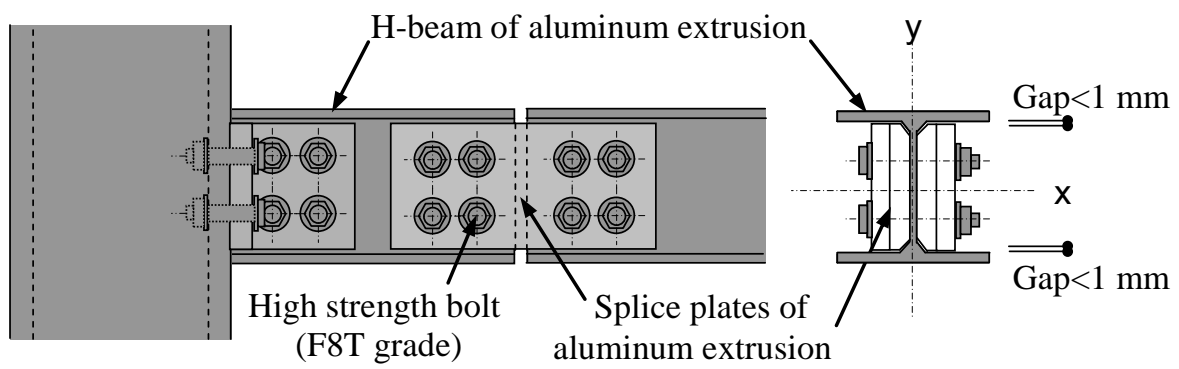

Fig. 4. Aluminum H-beam with web-bolted moment joint.

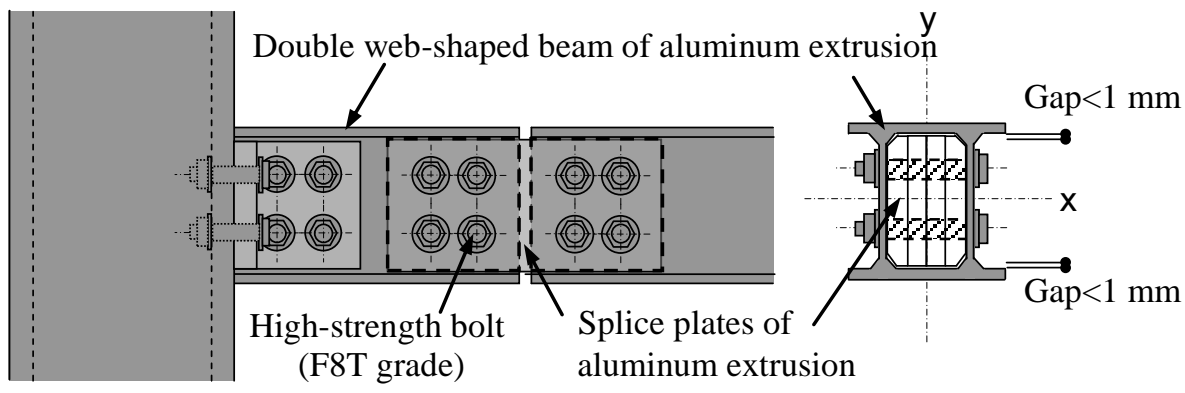

Fig. 5. Aluminum double web-beam with web-bolted moment joint.

In the fire case, good structural performance is expected from the frame, and the connection is not expected to fail prematurely before the frame collapse temperature [5]. Therefore, it is necessary to understand the maximum bending strength and the fracture properties of the joints in fire-engineering designs. However, there are no studies focusing on the maximum bending strength in beams subjected to the heat of a fire, although there have been studies on the tensile components of high-strength bolt friction joints in aluminum alloy members [7] and tensile tests at high temperatures [5].

This study narrows the application temperature field of aluminum alloy to $350{ }^{\circ} \mathrm{C}$ or less, and examines the transformation of strength properties in web-bolted moment joints. The purpose of the study is to clarify the fracture properties in fire engineering designs of an aluminum alloy structures with maximum bending moments in the joints.

\section{EXPERIMENT AND ANALYSIS}

A bending strength experiment was conducted to clarify the maximum bending strength and fracture properties of the web-bolted moment joint for the H-beam [4] and double web-beam at elevated temperatures. The beam length was $600 \mathrm{~mm}$. 
The bolt layouts of the joints are shown in Fig. 6 and the experimental conditions are listed in Tables 1 and 2. The lengths and temperatures of the section shape, the splice plates, the bolt layouts, and the beam material were considered as factors affecting the bending strength and transfer performance in the webbolted moment joints. The bolt layouts, the temperatures of the bolts, and the lengths of the splice plates are compared by varying the five factors affecting bending strength: the bolt layout, temperature, beam material, the double web-beam shape and the H-beam shape [3]. Figures 7a and b show the results of the double-web beam at room temperature and $300{ }^{\circ} \mathrm{C}$, respectively. Figures $8 \mathrm{a}$ and b show the results of the H-beam.
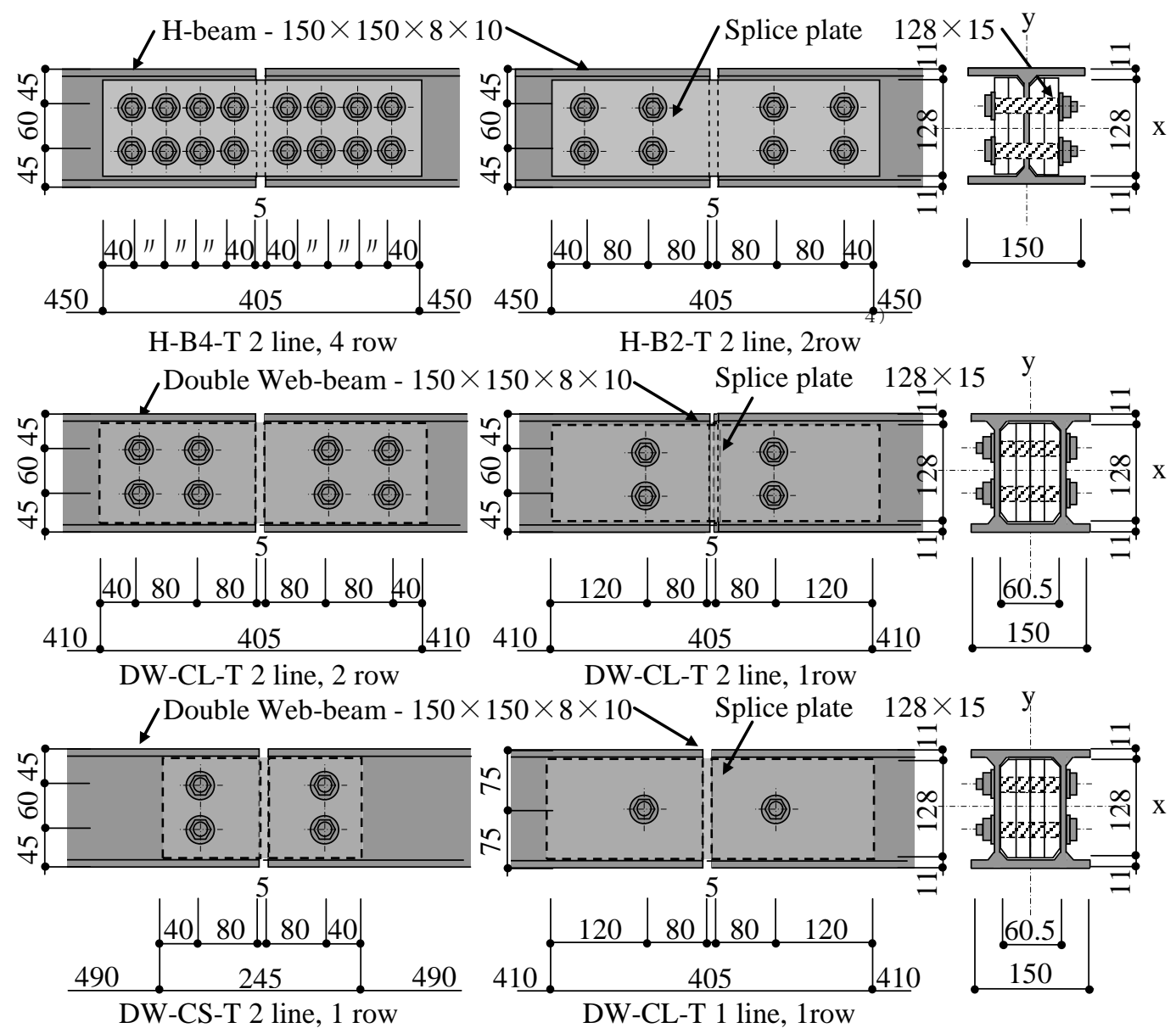

DW-CL-T 2 line, 1row

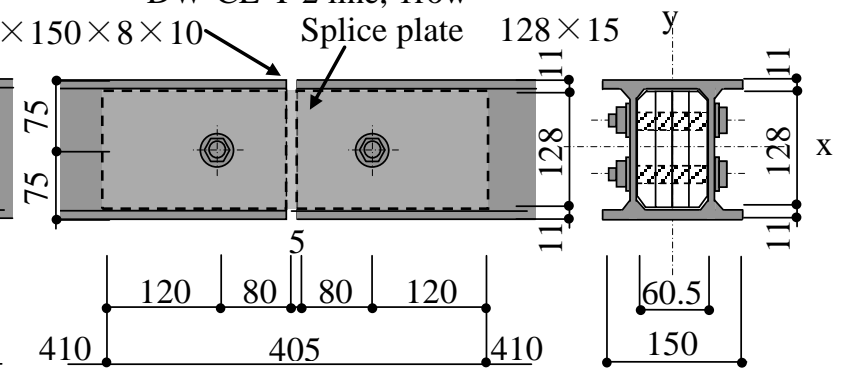

DW-CS-T 2 line, 1 row

DW-CL-T 1 line, 1row

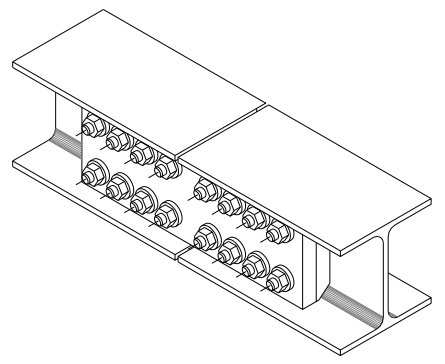

H-Beam

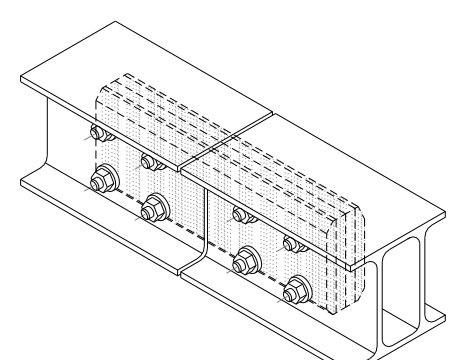

Double web beam

Fig. 6. Bolt arrays of specimens (for one joint). 
Table 1. Bending experimental conditions of double-web beam.

\begin{tabular}{|c|c|c|c|c|}
\hline $\begin{array}{c}\text { Splice plate } \\
\text { length (mm) }\end{array}$ & Bolts array & $\begin{array}{c}\text { Room } \\
\text { temperature }\end{array}$ & $\mathbf{2 0 0}^{\circ} \mathbf{C}$ & $\mathbf{3 0 0}^{\circ} \mathbf{C}$ \\
\hline No joint & No splice plate & B0-C0-T000 & B0-C0-T200 & B0-C0-T300 \\
\hline 405 & 1 line 1 row & B1-CL-T000 & B1-CL-T200 & B1-CL-T300 \\
\hline 405 & 2 line 1 row & B2-CL-T000 & B2-CL-T200 & B2-CL-T300 \\
\hline 405 & 2 line 2 row & B4-CL-T000 & B4-CL-T200 & B4-CL-T300 \\
\hline 245 & 2 line 1 row & B2-CS-T000 & B2-CS-T200 & B2-CS-T300 \\
\hline
\end{tabular}

Table 2. Bending experimental conditions of H-beam [4].

\begin{tabular}{|c|c|c|c|c|c|c|}
\hline Bolts array & RT & $\mathbf{1 0 0}^{\circ} \mathbf{C}$ & $\mathbf{2 0 0}^{\circ} \mathbf{C}$ & $\mathbf{2 5 0}^{\circ} \mathbf{C}$ & $\mathbf{3 0 0}^{\circ} \mathbf{C}$ & $\mathbf{3 5 0}^{\circ} \mathbf{C}$ \\
\hline No splice plate & B0-T000 & B0-T100 & B0-T200 & B0-T250 & B0-T300 & B0-T350 \\
\hline 2 line 2 row & B2-T000 & B2-T100 & B2-T200 & B2-T250 & B2-T300 & B2-T350 \\
\hline 2 line 4 row & B4-T000 & B4-T100 & B4-T200 & B4-T250 & B4-T300 & B4-T350 \\
\hline
\end{tabular}

In these figures, vertical axis shows the ratio between experimental moment and plastic one at room temperature and horizontal axis shows the ratio between experimental deflection slope angle and limited one $1 / 150 \mathrm{~mm}$.

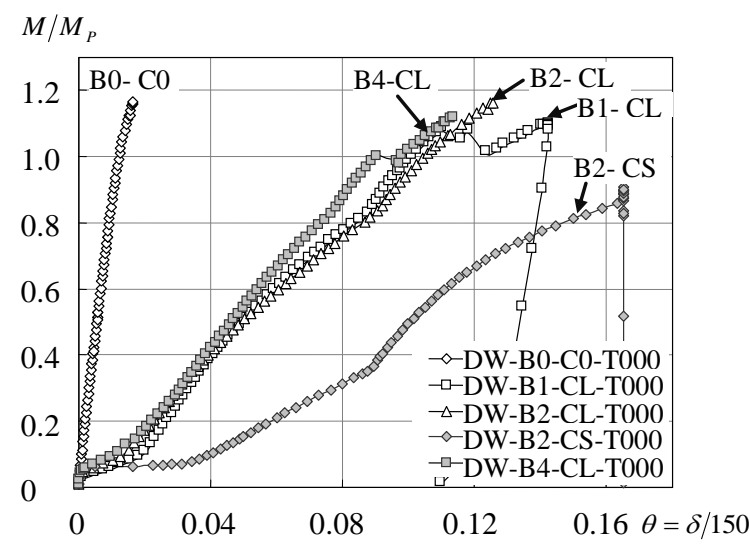

(a)

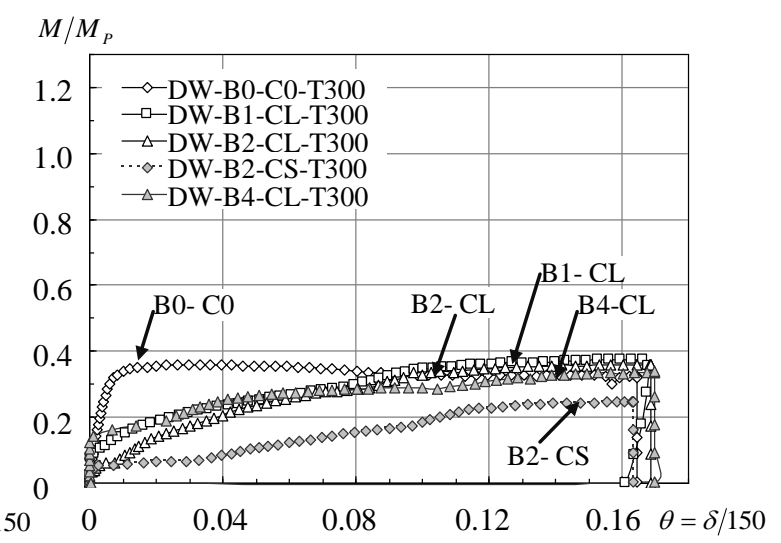

(b)

Fig. 7. Experimental result Double web-beam of: (a) room temperature; (b) $300{ }^{\circ} \mathrm{C}$.

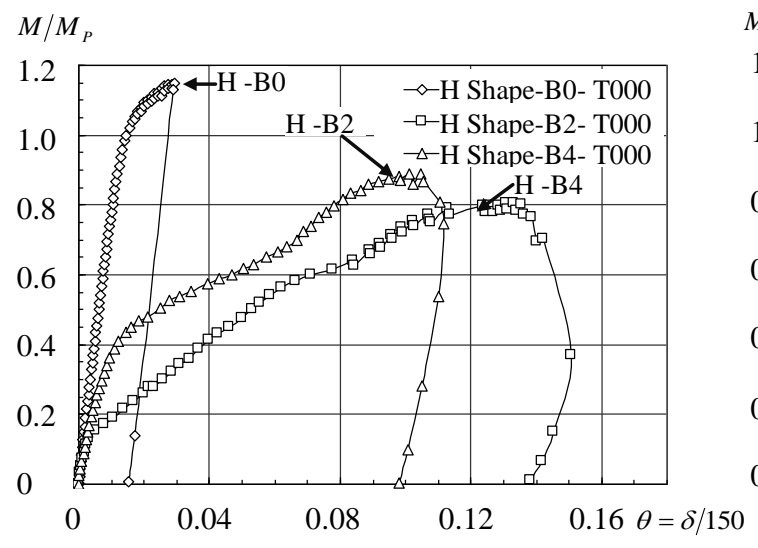

(a)

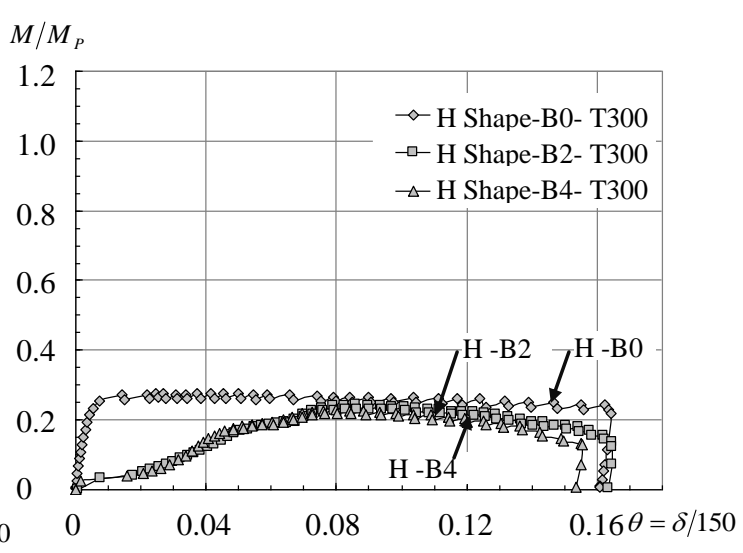

(b)

Fig. 8. Experimental result H-beam of: (a) room temperature; (b) $300{ }^{\circ} \mathrm{C}$. 


\section{The Maximum Bending Strength and Factors Affecting the Strength}

In the web-bolted moment joints of the double-web beam (excluding the joint of splice plate length $245 \mathrm{~mm}$ ), at room temperature and at $300{ }^{\circ} \mathrm{C}$, the maximum bending strength was found to be equal to the beam with no joints (See Figs. 7a and b).

In the H-beam, at room temperature the maximum bending strength occurred for the beam with no joints, although at $300{ }^{\circ} \mathrm{C}$ and $350{ }^{\circ} \mathrm{C}$ the beam with no joints had a bending strength of $70 \%$ of the maximum bending strength of that up to $250{ }^{\circ} \mathrm{C}$ [4] (See Figs. 8a and b).

It was concluded that the splice plate length is a factor affecting the maximum bending strength. In the double-web beam, $150 \mathrm{~mm}$ in width between the two webs, it was concluded that the splice plate length was a factor affecting the maximum bending strength. The beam with splice plates $245 \mathrm{~mm}$ in length had about $70 \%$ of the maximum bending strength of the beam that had a $405 \mathrm{~mm}$ splice (see Figs. $7 \mathrm{a} \mathrm{and} \mathrm{b}$ ).

In summary, the length of the splice plate greatly influences the maximum bending strength. The effect of the bolt arrays is minimal, even though the bolt array was assumed to be a factor. The equal, maximum bending strength was as a result of either one row one step ( 1 bolt) or two step two rows (4 bolts) (see Fig. 7a).

\section{Collapse Properties}

The deflection of the H-beam [4], and double-web beam and the rotation angle were not affected by the presence or absence of joints when the temperature exceeded $300{ }^{\circ} \mathrm{C}$, and the fracture was up to 0.16 (four times value of the allowable limit indicated in ISO834) (see Fig. 9 and Fig. 10).

The joints did not easily collapse at $300{ }^{\circ} \mathrm{C}$ or higher, although there were specimens that collapsed after reaching the maximum bending strength at room temperature up to $250{ }^{\circ} \mathrm{C}$ (see Fig. 11). It was clarified that the work hardening and elongation at $250^{\circ} \mathrm{C}$ and below were smaller for the aluminum alloy compared with steel, as shown by tension tests at elevated temperature.

In the $\mathrm{H}$ - beam, edge of collapse of the web occurred for specimens at room temperature up to $250{ }^{\circ} \mathrm{C}$ [4] (see Fig.13). In the double-web beam, punching shear caused tensile collapse of the flange (see Fig. 11) and near the web fillet (see Fig. 12). At $250^{\circ} \mathrm{C}$ or less, the concentrated stress easily causes brittle collapse.

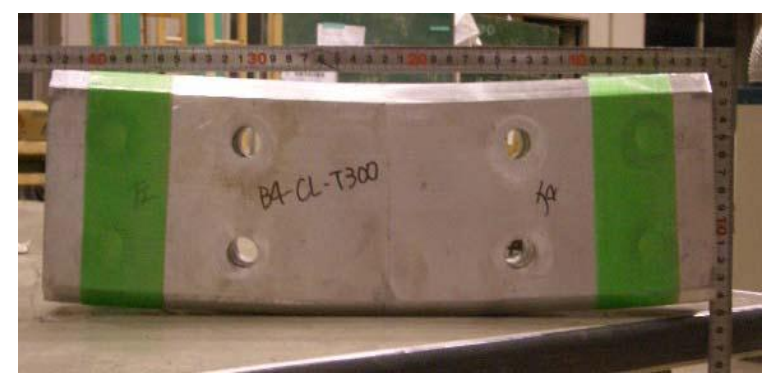

Fig. 9. Photograph of 2 line 2 row at splice plate $300^{\circ} \mathrm{C}$ in double web-beam experimental result. 


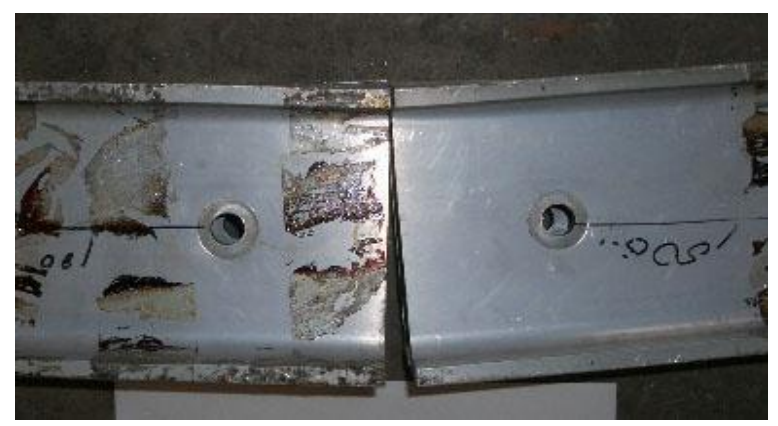

Fig. 10. Photograph of 1 line 1 row at beam joint $300^{\circ} \mathrm{C}$ in double web-beam experimental result.

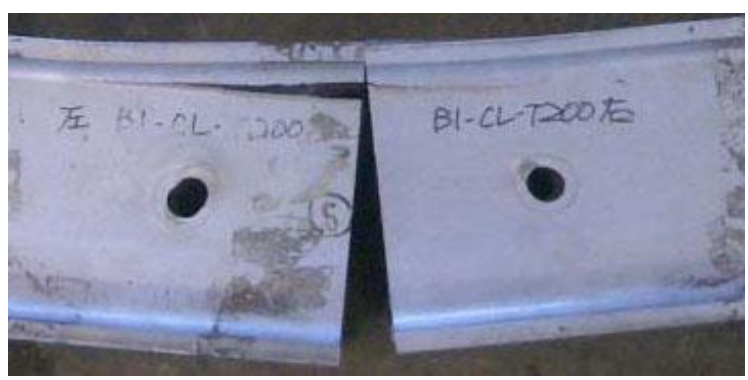

Fig. 11. Photograph of 1 line 1 row at beam joint $200{ }^{\circ} \mathrm{C}$ in double web-beam experimental result.

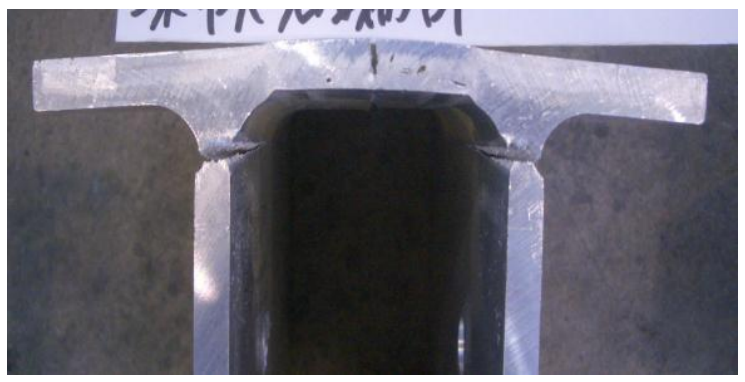

Fig.12. Photograph of 1 line 1 row at beam joint edge $200{ }^{\circ} \mathrm{C}$ in double web-beam experiment result.

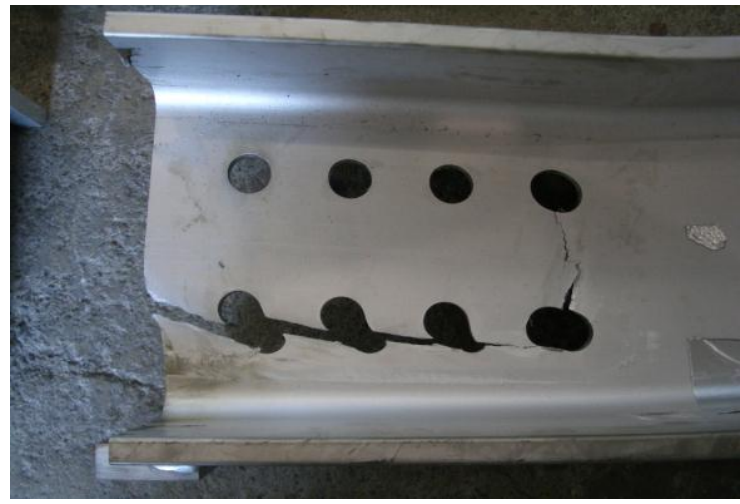

Fig. 13. Photograph of 2 line 4 row at beam joint $100^{\circ} \mathrm{C}$ in H-beam experimental result [4]. 


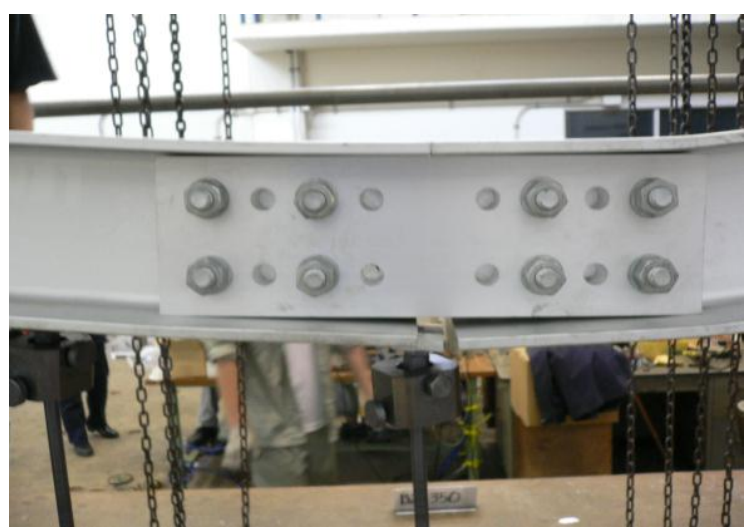

Fig. 14. Photograph of 2 line 2 row at beam joint RT in H-beam experimental result[4].

\section{Effect of Prying Action}

At $200{ }^{\circ} \mathrm{C}$ or higher in the high-strength bolt friction joint in the aluminum alloy, the bolt axis force decreases and tensile strength decreases rapidly, this decreasing phenomenon has been previously reported [7].

Due to the decrease of axis force in the high-strength bolt because of the rise in temperature, prying action is generated, as a result of bearing between the splice plate and the flange (see Fig. 14). Therefore, positive transmission of the bending moment is predicted by the prying action and not by the bending moment in the joint. It is thought that it is advantageous to be able to reduce the gap between the splice plates side edge and the flange when prying action is used.

In this study, it was assumed that transfer of bending moment is possible by prying action, and modeling of the web bolted moment joint of the prying action of the aluminum alloy beam was considered (see Fig. 15).

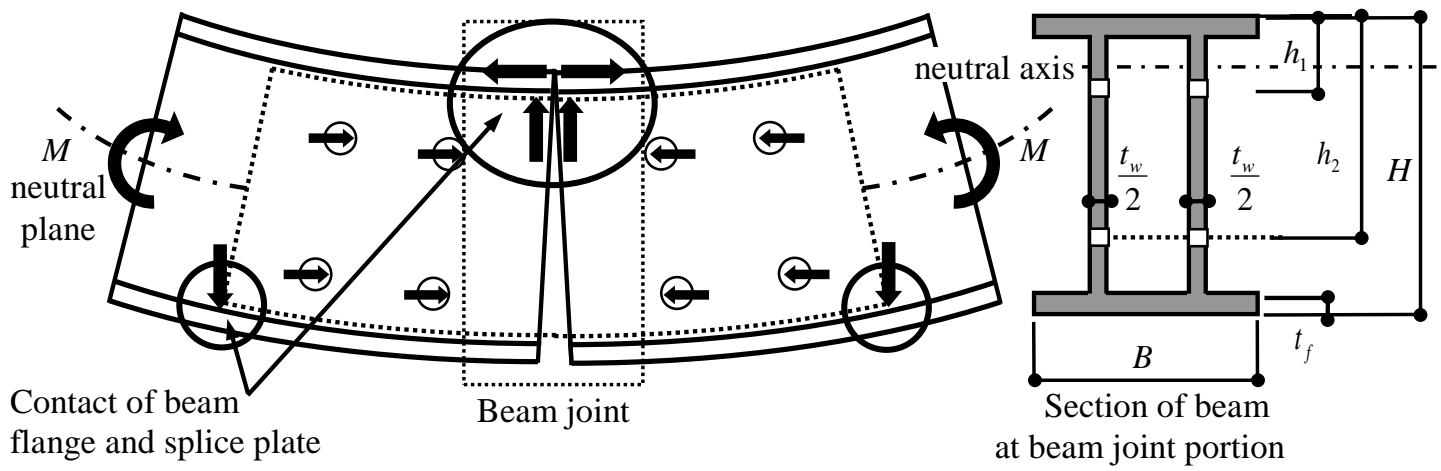

This indicates are contact of beam flange and splice plate.

Fig. 15. Generation of prying reaction and bearing action in beam joint force.

The transmission of the bending moment with the web-bolted moment joint of the aluminum alloy beam is frictional at first, and after slipping there is rotation at the bolt section due to shearing of the bolt and bearing of the web plate. However, in this study, prying action by the bearing with the bolt between the web, splice plates, and beam flange is expected without transmission of the frictional bending moment.

The bearing influence on the bolts and the prying action between the beam flange and the splice plate was examined. The load ratio of the prying action between the splice plate and the maximum bending bearing force of the web-bolted moment joint and the flange was quantitatively evaluated by experiment. Figure 16 shows the model used. The bending strength ratio of prying action reached $90 \%$ from $60 \%$ of the maximum bending strength (see Fig. 18a). 
Moreover, when a finite element analysis is conducted, the load ratio of the prying action, as shown in Fig. 17, was quantified and the result was different from that of the experimental result. In this case, the bending strength ratio of prying action reached $90 \%$ from $70 \%$ of the maximum bending strength (see Fig. 18b).

It is concluded that the bending moment with a web-bolted moment joint of an aluminum alloy beam is transmitted by friction, bearing, and prying action. Especially, it was clarified that the bending strength ratio of the prying action reaches $90 \%$ from $60 \%$ of the maximum bending strength.

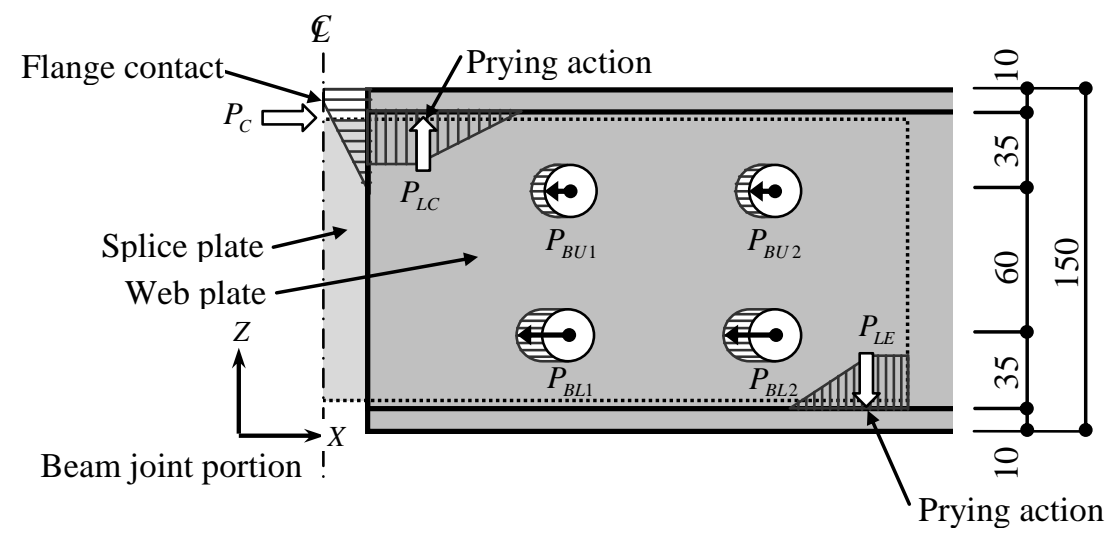

Fig. 16. Transmission model of force in web-bolted moment joint (double web).

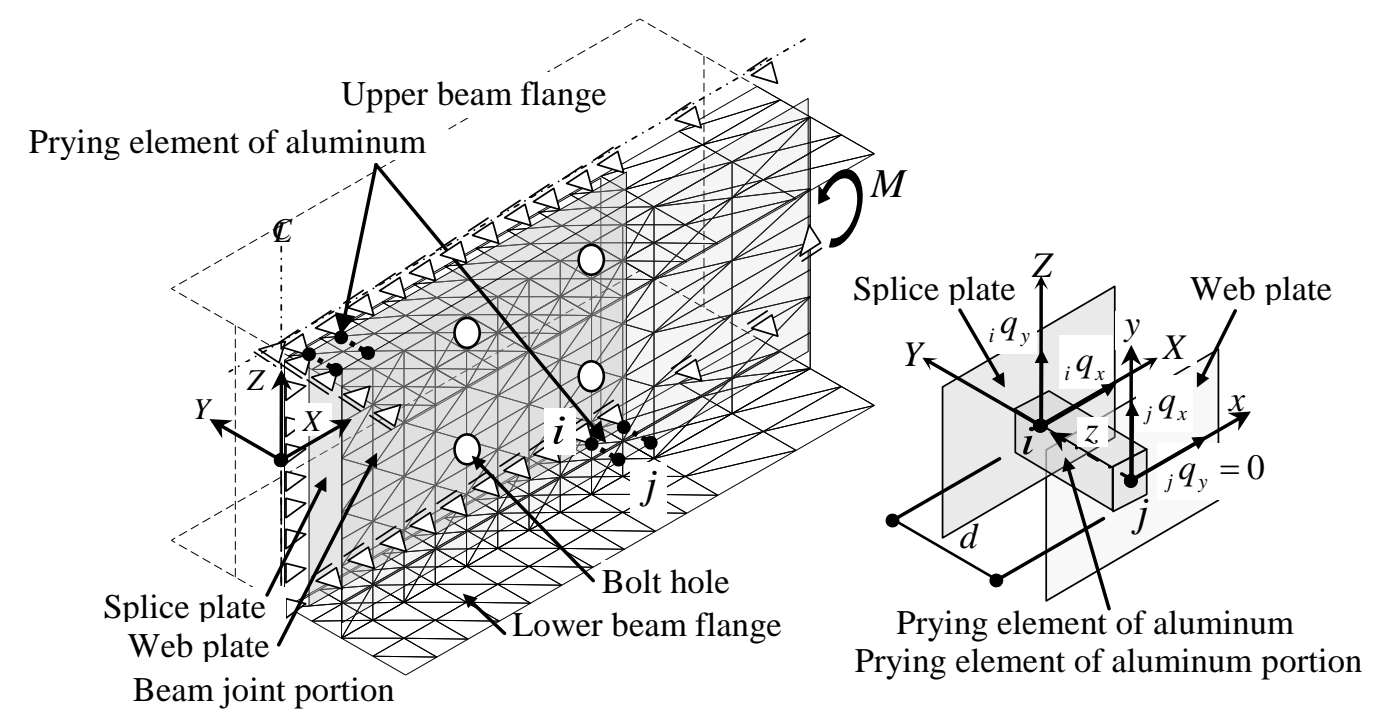

Fig. 17. Analytical model (double web). 


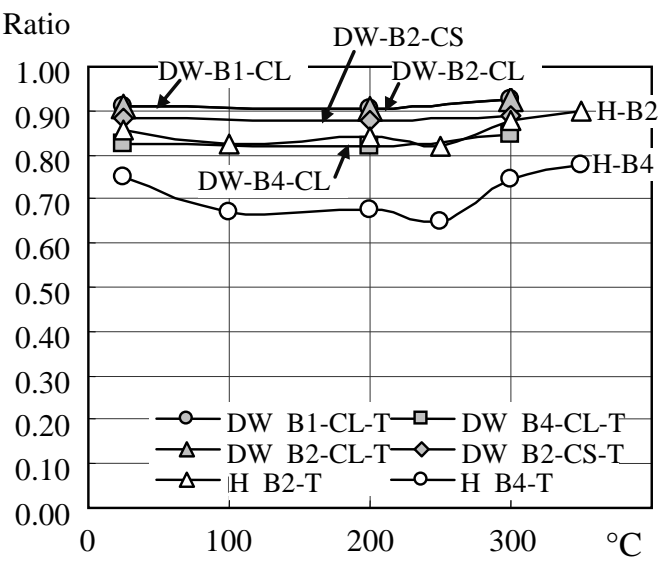

(a)

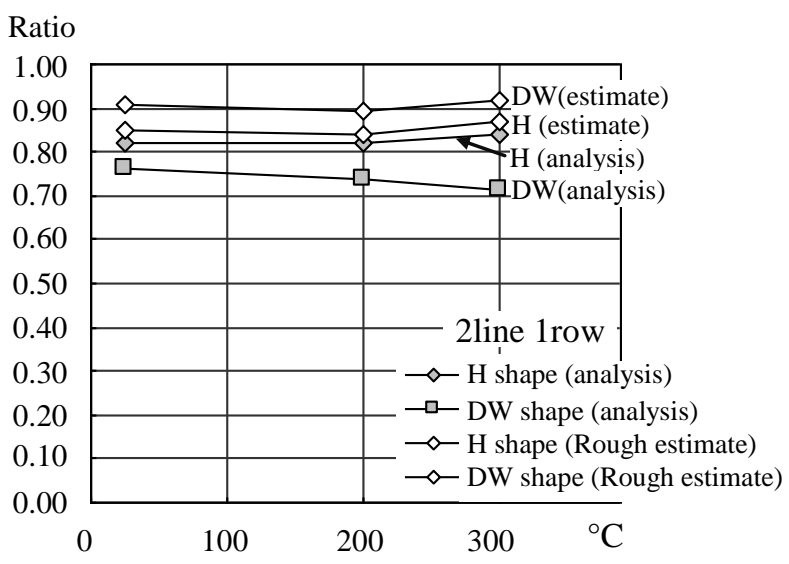

(b)

Fig. 18. Prying action ratio of: (a) experimental result (rough estimate); (b) analysis result and rough estimate.

\section{CONCLUSION}

The following mechanisms of bending strength for the H-beam and double-web beam of aluminum alloy were observed experimentally and analytically.

1) The maximum bearing moment of the beam with the double web-bolted moment joint is almost equal to the moment of a beam without a joint. For H-beams it is $70 \%$.

2) The effect of prying action contributes to the maximum bending strength. Prying action ratio is 90 $60 \%$ of maximum bending strength.

3) In specimens tested in the range of room temperature to $250{ }^{\circ} \mathrm{C}$, there was tensile fracture by the bearings, prying action between the boundary of the web and the flange portion, and punching shear fracture.

4) For the specimens tested at $300{ }^{\circ} \mathrm{C}$ and $350{ }^{\circ} \mathrm{C}$, because the bending transformation by the prying action had progressed, brittle fracture was not seen.

When the web-bolted moment joint was used, valuable data concerning the bending moment transmission at fire temperatures was obtained. In the aluminum alloy structure, it is necessary to secure the toughness of the joint section if sustained loading was expected so that collapse is avoided at $300{ }^{\circ} \mathrm{C}$ or above. In the past, there has been no standard method concerning joints in the design of fire resistance in aluminum architectural structures. Information for fire resistance of the joints of aluminum structures was presented in this paper.

\section{FUTURE TASKS}

The following studies must be conducted:

1) Clarification of the behavior of beams subjected to shearing force.

2) Establishment of a design formula based on bending in the shearing study.

3) Development of practical section distribution of the prying force.

\section{REFERENCES}

[1] Niwa, H., Zhou, Z.M., Kuramoto, S., Uesugi, H., Saito, H., and Ohyama, H., (1994) Web bolted moment joint of $\mathrm{H}$ shape steel beam, Journal of Structural Engineering, Architectural Institute of Japan, 40B: 695-702 (in Japanese).

[2] Architectural Institute of Japan, "Recommendation for Design of Connections in Steel Structures", 2006 (in Japanese). 
[3] Jiang Liang, G., Uesugi, H., Ohyama, H., Nakagawa, J., and Saito, H., Analysis of Web-Bolted Moment joint for $\mathrm{H}$ Shaped Steel Member, $28^{\text {th }}$ Safety Engineering Symposium, 1998 (in Japanese).

[4] Hirayama, M., Ishii, H., Hirashima, T., and Uesugi, H. (2006) Experimental study about bending capacity of aluminum $\mathrm{H}$ shaped beam with web-bolted moment connection at elevated temperature, Journal of Structural Engineering, 52B: 401-408 (in Japanese).

[5] Building Research Institute Supervision, "Standard for Design of Fire Resist in Aluminum Architectural Structure", 2003, pp. 53-58 (in Japanese).

[6] Honda, K., and Uesugi, H., Developed on Techniques of Effective Use of New Metallic Materials for Building Structures (Comprehensive Project on New \& Advanced Materials): Part 92 Tension Test of Aluminum Alloys at Elevated Temperature, Summaries of Technical Papers of Annual Meeting Architectural Institute of Japan, 1993 (in Japanese).

[7] Nakagome, T., Ichikawa, Y., Kosaka, Y., and Inokuma, T., (2002) High strength bolt friction joint experiment which high temperature heating is received, Journal of Structural Engineering, 48B: $105-110$ (in Japanese). 